\title{
Teaching Math to My Scholars: Inner City Middle School Students
}

\author{
Ranjani Iyer ${ }^{1} \&$ Joseph Pitts ${ }^{1}$ \\ ${ }^{1}$ Michigan Technical Academy, Michigan, USA \\ Correspondence: Ranjani Iyer, Michigan, USA. E-mail: home.ranjani@gmail.com
}

Received: March 10, 2017

Accepted: April 11, $2017 \quad$ Online Published: May 4, 2017

doi:10.5539/jel.v6n3p243

URL: http://doi.org/10.5539/jel.v6n3p243

\begin{abstract}
Teaching in an inner city school requires classroom management, resilience, and most importantly strategies to promote learning and growth. There is a constant need for acceleration in student growth in core subjects, especially Math. A blended learning model can be an effective option for schools to personalize learning experiences for students and cater to individual needs for effective learning. Blended learning classes produce statistically better results than their face-to-face, non-hybrid equivalents (U.S. Department of Education, 2010). The purpose of this article is to analyze student demographics as it relates to student performance in an inner city school. As a teacher, you probably need to be one of the most flexible people in the world (Featherstone et al., 1997). Educators need to use learning activities that are both fun and relevant to the students' present body of knowledge to master and comprehend math skills. The authors discuss strategies that can be utilized to enhance and promote student performance and growth. Also, elements of educational methodology based on the author's experience are discussed and its influences on student performance.
\end{abstract}

Keywords: inner city, middle school, math, strategies, student performance, academic growth

\section{Introduction}

\subsection{An Introduction}

Teaching in an inner city school is a challenging and a great experience. Classroom management is a top priority. Nothing can prepare an educator for what holds a key to effective teaching, even a doctorate degree in Education and global experience in teaching middle school students. Learning how to teach is not possible without the ups and downs in a real classroom environment.

As Nelson Mandela once stated, "Education is the most powerful weapon you can use to change the world". I grew up in India with several role models who were educators and I have always aspired to teach. With several years of teaching in the U.S. and India, it was exciting to take up an opportunity to teach in an inner city charter school in Detroit. The blended design, with teaching and technology as critical components, the school seemed to be a great fit for my background. A foundational belief of "effective teaching is the key to effective learning" is well supported by a strong team of administrators consisting of the Principal, Director of Personalised Learning (DPLs), and District Support Specialists. Customizing lesson plans and a personalized learning model assist in supporting student learning and overall academic performance. The four step continual learning process model as part of a technology rich education used by the school enables students to be met where they are, progress when ready based on demonstrated applied mastery, and exercise agency over their own learning resulting in higher accountability (Matchbook, 2016). The unique learning management platform known as Spark, forms a learning community ideal for the $21^{\text {st }}$ century of teaching and learning.

The acceleration of growth needs to increase in core subjects. In order to address the necessary increase, improvements are occurring in the areas of curriculum structure, continuing best practices that made initial gains, content specific support and training, content specific tools, as well as accountability including follow-up, monitoring, and adjustments based on data.

A blended learning model can be an effective option for schools to personalize learning experiences for students and cater to individual needs for effective learning. This model combines face-to-face instruction with online learning tools to enhance learning, resulting in better academic performance. Blended learning classes produce statistically better results than their face-to-face, non-hybrid equivalents (U.S. Department of Education, 2010). Blended learning models can also be utilized to teach and build perseverance. Using such models and online tools, support students to simplify the challenging parts in a given problem, articulate strategies to problem 
solving thus making the problem simpler and the student smarter. Asking the students thought-probing questions as they explore is the key to learning. Students in a blended learning model have the opportunity to independently conceptualize concepts, and persevere in problem-solving situations. This is in direct opposition to a classroom where teachers articulate and demonstrate formulas, procedures, and rules that only some students can emulate. Even such students often lack an understanding of the concept, nor can articulate a conceptual application of the process of solving math problems. For example, students are given lessons on "borrowing" or "regrouping" without understanding the base-10 number system.

Apart from the blended learning model that the school offered, there were several reasons for me to join the team. I always wanted to make an impact on students especially teenagers. The demands of teaching middle schoolers is visible in teacher retention rates. The young adolescent psyche is a challenge to manage. Students who have seen little success in the classroom have low expectations of anyone who attempts to challenge them academically. Soon frustration, contempt and despair can pose as extra barriers. Coupled with academic deficiencies, a classroom teacher must find ways to connect and cope. The practice of meditation since high school, necessary for my resilience and patience as an educator, was being tested.

In this school, $100 \%$ of the student population is of African-American ethnicity. According to the results of the 2015 National Assessment of Educational Progress tests published by the Department of Education's National Center for Educational Statistics, in the Detroit public school district, $96 \%$ of eighth graders lack proficiency in mathematics and 93\% in reading (NCES, 2015). The performance gap was significantly higher in African-American students. To address this challenge, schools needed a highly qualified teacher in the subject area and the teaching of mathematics needed to be connected to real life experiences of African-American students.

\subsection{Learnings from the Past}

I started my teaching career in a middle school in Texas. The students used cooperative learning and peer support strategies to reason and deepen their understanding of mathematical concepts. The class was designed to enable students to explore with manipulatives and utilize online simulations as well as online games. Students gave and received constructive feedback to build upon their learning. The experiential learning was student-centered and simulation based. The first year of teaching was a rewarding and a learning experience.

My journey to India gave an exposure to various boards and methodologies of education adopted by different schools. In the following years of teaching there, I taught under 3 boards using different methodologies for teaching and instruction. Central Board of Secondary Education (CBSE), which is the Central board in India is content and textbook driven, it builds on a new system called Continuous and Comprehensive Evaluation (CCE) for assessing student progress. This board follows a universal pattern. The main focus is laid on theoretical knowledge and true emphasis is not laid in calculating practical knowledge and real-life concepts. Most of the time, teachers find it hard to complete the syllabus in the given amount of time. This board demonstrates how the rigor and practice in mathematics can be utilised to improve student performance.

International General Certificate of Secondary Education (IGCSE) is an academically rigorous and internationally practiced curriculum offered to students in middle school to prepare them for International Baccalaureate and CIE A-level instruction. The curriculum uses project-based learning to connect math and relate it to real life situations. Activities and teaching are more application and practical based. During my experience teaching under this board, students completed a project to deepen their understanding of money, finance and proportions through a "Cake Bake Sale". They enjoyed baking the goodies, advertising them, selling them, projecting their sales, accounting for the money spent and money earned, and donating the profit to a good cause. The overall experience of this project supported mathematical reasoning, problem solving skills and real life skills.

International Baccalaureate (IB) is an international educational foundation headquartered in Geneva, Switzerland and founded in 1968. This curriculum is based on application and experimentation catering to the learning profile of the student. This board provides an opportunity to engage the students to go deeper into a concept or a topic of interest. IB is a well-known international board developing students as well-rounded individuals in the $21^{\text {st }}$ century. Using a variety of activities, both individual and small groups, and technological help with smartboards, promotes an environment for mathematical discussions and growth. My math classrooms used debates to share reasoning and building ideas for problem solving. Discussion on interest (simple or compound) and how to use this understanding when we borrow or lend the money, was received with great enthusiasm from the students. The end of the year project of "Becoming an Entrepreneur" starting a restaurant, keeping in mind all the mathematics involved in budgeting and finance, was a tremendous success. The main focus of teaching 
and instruction here is on "how to learn" rather than "what to learn". All this learning from the past gave me a worldwide view to teaching and instruction, and helped in equipping me with strategies to cater to the diverse needs of my students wherever I am employed.

\section{Discussion: Strategies to Promote Growth}

In this global century, with fast growing influence of technology and its impact, it is very important for educators to embrace and utilize what is available. It is equally important to cater to the unique and diverse needs of the students through whole group, small group or one-on-one instruction to support them to reach their highest potential. One-size-fits-all education is long gone. As a teacher, you probably need to be one of the most flexible people in the world (Featherstone et al., 1997).

The first day in my new school was exciting and nerve wrecking as I prepared myself to meet my scholars. I felt totally prepared with all the professional development and learning from my past experiences. The main agenda for the day was to "connect" with my students. It went well with many of my students attempting to pronounce my last name and giggling when I would say their names. The students completed a short survey on their likes and dislikes. Many openly shared their disinterest in math. In the next few weeks, based on initial assessments, it was clear that my scholars were at least two grades behind their current grade-level in math. Although classroom management was a huge challenge, the "ah ha" moments were priceless where the students connected to basic mathematics.

Educators need to use learning activities that are both fun and relevant to the students' present body of knowledge to master and comprehend math skills. It can be taxing making learning math fun and relevant, creating a rapport with students, maintaining high expectations and finding effective ways to manage behaviors. It is important to understand the different learning styles of your students to implement a process suitable for them to learn effectively. Using different approaches to teaching and instruction is very helpful. Learning best practices from my colleagues, support from the school administration team, and my own experiences have helped. Some of the strategies worked and some not so well.

In a short period of time, as discussed below, multiple strategies were used to support student learning and performance.

Whole group instruction-Whole group instruction is the most traditional and common form of classroom organization (Ornstein, 1995). This uses minimal differentiation to introduce a new concept and sets a stage for the concept. Although this is mainly teacher-led, this helps in understanding previously learned skills and the depth of knowledge students possess. Note taking can be encouraged during the instruction. Teachers utilize the information gained from whole group instruction to plan for future instruction. This strategy is very helpful in my classroom to launch a unit. As Ornstein noted, bringing members of a class together for certain activities strengthens the feeling of belonging to a large group and can help establish a sense of community and class participation. This gets the whole class ready for the individual and small group activity to follow.

Small group instruction-This strategy focuses on a particular skill and enables the educator to differentiate instruction through a small group setting with a small number of students. Flexible small group instruction reaches all students at their level of development and takes them to the next level (Sammons, 2010). The whole group instruction sets a learning stage while small group brings a more focused approach and addresses the student's individual needs. This allows teachers to work more closely with the small group of students, reinforce skills learned in the whole group instruction, and assess for student understanding. The small group works together to master the learning objective. Research also suggests that good quality small group work positively affects student involvement in their academic studies generally and their capacity to apply learned concepts in new situations (Collier, 1983). My past experiences with small group instruction and cooperative learning have been very encouraging. The challenge in this activity is to maintain classroom discipline and create a conducive environment for the students to learn. As Slavin et al. reported, for the United States Department of Education research entitled, Educator's Guide: What Works in Teaching Math?, programs designed to change daily teaching practices - particularly through the use of cooperative learning, classroom management, and motivation programs - have larger impacts on student achievement than programs that emphasize textbooks or technology alone (2010, p. 3). Homogenous groups work better in my class than a group with mixed mathematical abilities. Students, relatively, start with the same level of understanding and are probed to deepen their knowledge through questioning and interaction amongst themselves. The teacher skillfully facilitates the discourse.

Student-led sessions - Teaching is the most effective way for learning. These sessions in my classroom promote peer learning and encourages an in depth understanding of the concept. Cooperative learning helps students to 
learn from one another other. Student facilitation encourages students to see the tutor as part of the group, which has a positive effect on student interaction and engagement in the group (Campbell, 2015). Campbell also noted in his study that students who have been less inclined to contribute become more vocal in student-led (and later tutor-led) sessions. Students take pride in leading such sessions and enjoy rewards associated with that as well.

Integrating technology - Teaching in my school utilizes technology integration to enhance the learning experience. The platform that the students use support online learning and practicing of the skills needed to understand a concept. Research has shown that effective technology integration across the curriculum deepens and enhances the learning process. New technological advances can not only help students learn better, but will also prepare them to adapt to the fast paced technological environment in the $21^{\text {st }}$ century. Despite the challenges that educators face in incorporating technology into their teaching and instruction, this has shown benefits in personalizing learning for the students. An interactive game is more engaging than a book, so technology often promotes more practice and review in areas requiring memorization, such as spelling, math and geography (Cleaver, 2014). The students in my school log into their school community and learn a concept individually through lessons on LearnZillion, Khan Academy, YouTube, and a variety of instructional tutorials. Utilizing apps like STmath, I-Ready, or Think Through Math, a student can work at his/her own pace to deepen their understanding of a mathematical concept.

Formative Assessment Lessons (FAL) - Engagement is the optimum classroom management tool. FALs are tools used to engage and explore a mathematical concept. FALs support teachers in promoting students' understanding of key mathematical ideas and applications. These lessons enable teachers and students to monitor their progress towards the targets of the standards through pre- and post-assessments. They also help in building mathematical reasoning and improves their problem solving abilities. These lessons start with a pre-assessment, followed by pairing group work and whole group instruction, and ends with a post-assessment to see the growth in understanding. The FAL on "Discovering Pythagorean Theorem" (available on http://map.mathshell.org/) was used successfully in my classroom to enable students to explore this new concept. This helped in moving away from just using the formula to deriving the formula themselves with the use of "tilted squares". Although middle school students usually look for instant gratification, these lessons provide a platform for productive struggle and exploration to deepen conceptual and applicative understandings.

This student-led method is designed to be challenging at any grade level and increases inquiry and stamina. The lessons are scripted, so the instructor avoids leading students in their thinking as opposed to discovering the concept by trial and error or applying prior knowledge. The idea is that the lesson is appropriately challenging for the student to deepen their thought process of a misconception or procedural math. The 5 basic strategies include: making learning intentions clear for students, designing effective questions that lead to evidence of learning, using feedback that actually moves learning forward, activating student agency, and activating students as resources for one another. The experience with the lessons have informed every aspect of my instruction. Students must persevere in every mathematical challenge and may not always solve every problem. The point for the learner is to reflect, show growth, and develop a clearer understanding through many means.

Real-life connections-Making real life connections and understanding the relevance of learning is key to effective teaching and learning. Relevance is important to teaching and learning because it is directly related to student engagement and motivation (Frymier \& Schulman, 1995; Martin \& Dowson, 2009). Basic mathematical skills including adding and subtracting become barriers to making this connection. If you really want students to engage in "higher-order thinking" in math, get them to master basic operations like their times tables first (Clavel, 2003). Connecting number sense, place value, fractions, integers, and in even inequalities to money and everyday finance created relevance for learning. In the lesson on graphs and linear functions, using examples from everyday lives, assisted many students with comprehending unfamiliar and often uncomfortable strategies and skills. Students in my class gained a better understanding of linear function by looking at their cell phone bills, how the variable cost and minutes used were connected, and how their bill traced a linear function. They were able to build other examples of linear functions in their own lives. As instructors, one of the most important things we do is provide relevance for students. It gives them a context within which they can develop into engaged, motivated and self-regulated learners (Roberson, 2013).

Integrating relaxation and positive Mondays - One of the ways to connect with my students was to help them connect with themselves. Relaxation and meditation techniques is gaining popularity in schools to reduce stress, improve emotional outlook and provide balance. In the California Achievement Test, twice as many students in Quiet Time schools (Quiet time is a stress reduction technique) have become proficient in English, compared with students in similar schools where the program doesn't exist, and the gap is even bigger in math (Kirp, 2014). 
Kirp also mentioned that "Teachers report they're less emotionally exhausted and more resilient" after using such programs in their classrooms. In schools in New York City and in pockets around the country, the use of inward-looking practices like mindfulness and meditation is starting to grow (Harris, 2015). The goal of mindfulness exercises, practitioners say, is to get students into the habit of calming themselves and their minds, says Lindsay Morris for The New York Times.

In the year 2015, Department of academic internal medicine, Wellspan York Hospital, Pennsylvania conducted a study on the impact of Heartfulness meditation program on health care providers. This study, recently published in the Journal of Community Hospital Internal Medicine Perspectives, found that participants experienced significant increase in joy, calmness, harmony, tolerance, confidence, sleep quality and other positive attributes. They also experienced significant decrease in anger, stress, anxiety, cynicism, fear, irritability and other negative attributes (Thimmapuram et al., 2017). Heartfulness programs are also being implemented in several schools in the U.S. in Texas, Michigan, New Jersey, New York, Connecticut, North Carolina. Educators and students are observing benefits of the program in reducing stress, anger, and building calmness, focus and concentration. The simple act of Heartfulness meditation even for 15 minutes every day regulates the mind and relaxes the body and centers it in the heart.

In my class, we start our Mondays with a couple of minutes of Heartfulness relaxation and breathing. This is followed by sharing something positive that happened over the weekend and anything exciting upcoming. If there is nothing to share, a student would just say "I am happy to be here". This helps create a good start to the week. Believing in oneself is lacking in many students. Using heartful affirmations and positive suggestions help in bringing up that belief that the students can do anything they put effort in, even solving math problems. Effort creates ability.

Parental Support - Students with parents who are involved in their school tend to have fewer behavioral problems and better academic performance, and are more likely to complete high school than students whose parents are not involved in their school (Henderson \& Berla, 1994). A recent meta-analysis showed that parental involvement in school life was more strongly associated with high academic performance for middle schoolers than helping with homework (Hill \& Tyson, 2009).

Usually when a parent receives a call from the school, they are expecting complaints or warnings regarding the child's behavior and performance. I have made several calls to parents for the same reason and have received support from many for the welfare of the child. I have also made positive phone calls to congratulate parents on their child's performance. This comes as a welcoming surprise to many. This creates a culture of mutual respect between the teacher and the family that fosters the belief that students with support will reach their fullest potential.

\section{Conclusion}

The most formidable challenge in teaching mathematics in an inner city school is to create interest in math, and making the learning relevant and real. Charter schools are consistently working hard to support and serve students who have yet to perform well at other schools. There is a definite hope with my school and colleagues believing in me and supporting our students, using phrases such as "falling forward". This encourages them to know that even when they fall they have the opportunity to move forward through the learning processes. Another mantra, "perfect practice makes perfect and permanent" reinforces practicing to get to perfection. We understand that practice doesn't make perfect, but, it is the perfect practice that makes permanence. The idea of permanence is to be able to apply math today, tomorrow and many years later. This is a huge effort in managing issues related to student behavior and focusing on student-teacher relationships. It is not easy being a teacher with a different ethnicity and background, to connect and relate to the day-to-day challenges that my scholars face, and supporting them in bringing out their best. The main motivation for me as an educator is to see the joy in them in learning. It is rewarding to see the students growing in mathematical reasoning and connecting mathematics in their daily lives, even though this might be a little at a time. The expectation in my school is "Excellence" and we are all thriving towards that. Many schools empower educators in implementing research-based strategies to support teaching and instruction, and are working hard to do all the right things in creating an education option for students. There is still a challenge in inner city schools, like mine, in balancing the act of classroom management and purposeful teaching. As an educator, it is an accomplishment to reflect that learning is taking place and positive experiences are happening. 


\section{References}

Campbell, E. (2015). Students as Facilitators: An evaluation of student-led group work. Practitioner Research in Higher Education, 9(1), 52-58.

Clavel, M. (2003). How not to teach Math. Retrieved December, 2016, from http://www.city-journal.org/html/how-not-teach-math-9991.html

Cleaver, S. (2014). Technology in the classroom: Helpful or Harmful? Retrieved April, 2017, from https://www.education.com/magazine/article/effective-technology-teaching-child/

Collier, K. G. (1983). The Management of Peer Group Learning: Syndicate Methods in Higher Education. Guildford: Society for Research into Higher Education.

Featherstone, D., Munby, H., \& Russell, T. (1997). Finding a voice while learning to teach. Taylor \& Francis, Inc: Bristol, PA.

Formative Assessment Lessons. (2017). Retrieved March, 2017, from http://map.mathshell.org/lessons.php

Frymier, A. B., \& Schulman, G. M. (1995). "What's in it for me?" Increasing content relevance to enhance students' motivation. Communication Education, 44, 40-50. https://doi.org/10.1080/03634529509378996

Harris, E. A. (2015). Under Stress, Students in New York Schools Find Calm in Meditation. Retrieved January, 2017, from https://www.nytimes.com/2015/10/24/nyregion/under-stress-students-in-new-york-schoolsfind-calm-in-meditation.html?em_pos=large\&amp;emc=edit_nn_20151104\&amp;nl=morning-briefing\&am p;nlid=72771963\&amp; r $=2$

Heartfulness Institute. (2017). Retrieved March, 2017, from http://en-schools.heartfulness.org/

Henderson, A. T., \& Berla, N. (1994). A new generation of evidence: The family is critical to student achievement. Washington, DC: National Committee for Citizens in Education.

Hill, N. E., \& Tyson, D. F. (2009). Parental involvement in middle school: A meta-analytic assessment of the strategies that promote achievement. Developmental Psychology, 49(3), 740-763. https://doi.org/10.1037/a0015362

Kirp, D. L. (2014). Meditation transforms roughest in San Fransisco schools. Retrieved January, 2017, from http://www.sfgate.com/opinion/openforum/article/Meditation-transforms-roughest-San-Francisco-5136942. php

Martin, A. J., \& Dowson, M. (2009). Interpersonal relationships, motivation, engagement, and achievement: Yields for theory, current issues, and educational practice. Review of Educational Research, 79, 327-365. https://doi.org/10.3102/0034654308325583

Matchbook Model. (2016). Retrieved December, 2016, from http://www.matchbooklearning.com/why-matchbook/model-why/

NCES. (2015). Retrieved January, 2016, from https://nces.ed.gov/nationsreportcard/subject/publications/dst2015/pdf/2016049XR8.pdf

Ornstein, A. C. (1995). Synthesis of Research: Teaching whole-group classrooms. Peabody Journal of Education, 70(2), 104-116. https://doi.org/10.1080/01619569509538825

Roberson, R. (2013). Helping students find relevance. Psychology Teacher Network. Retrieved April, 2017, from http://www.apa.org/ed/precollege/ptn/2013/09/students-relevance.aspx

Sammons, L. (2010). Guided math: A framework for mathematics instruction. Huntington Beach, CA: Shell Education Publishers.

Slavin, R. E., Lake, C., \& Groff, C. (2010). Educator's guide: What works in teaching math? In Best Evidence Encyclopedia. United States Department of Education. Retrieved from http://www.bestevidence.org/word/math_jan_05_2010_guide.pdf

Thimmapuram, J., Pargament, R., Sibliss, K., Grim, R., Risques, R., \& Toorens, E. (2017). Effect of heartfulness meditation on burnout, emotional wellness, and telomere length in health care professionals. American Journal of Community Hospital Internal Medicine Perspectives, 7(1), 21-27. https://doi.org/10.1080/20009666.2016.1270806 
U.S. Department of Education. (2010). Evaluation of Evidence-Based Practices in Online Learning: A Meta-Analysis and Review of Online Learning Studies. Retrieved January, 2017, from https://www2.ed.gov/rschstat/eval/tech/evidence-based-practices/finalreport.pdf

\section{Copyrights}

Copyright for this article is retained by the author(s), with first publication rights granted to the journal.

This is an open-access article distributed under the terms and conditions of the Creative Commons Attribution license (http://creativecommons.org/licenses/by/4.0/). 